Relations industrielles

Industrial Relations

\title{
Harbridge, Raymond, ed., Employment Contracts: New Zealand Experiences
}

\section{Kurt Wetzel}

Volume 48, numéro 4, 1993

URI : https://id.erudit.org/iderudit/050909ar

DOI : https://doi.org/10.7202/050909ar

Aller au sommaire du numéro

Éditeur(s)

Département des relations industrielles de l'Université Laval

ISSN

0034-379X (imprimé)

1703-8138 (numérique)

Découvrir la revue

Citer ce compte rendu

Wetzel, K. (1993). Compte rendu de [Harbridge, Raymond, ed., Employment

Contracts: New Zealand Experiences]. Relations industrielles / Industrial

Relations, 48(4), 793-794. https://doi.org/10.7202/050909ar

Tous droits réservés (c) Département des relations industrielles de l'Université Laval, 1993
Ce document est protégé par la loi sur le droit d'auteur. L'utilisation des services d'Érudit (y compris la reproduction) est assujettie à sa politique d'utilisation que vous pouvez consulter en ligne.

https://apropos.erudit.org/fr/usagers/politique-dutilisation/ 
relations systems) to a number of possible explanations for divergence between systems which were once closely matched. At the same time however, it should be noted that a model which accounts thoroughly for divergence between systems remains elusive. Size of labour market, greater industrial diversification, employer strategies, and union influence on Labour Parties are all offered as potential reasons for a parting of the Tasman waves. Unfortunately, without an explicit attempt to theorize these developments, one is left wondering what the key explanatory variable(s) really is. Nevertheless, for scholars who wish to address this question, this Monograph clearly offers a constructive point of departure.

Clive H.J. GiLson

\section{St. Francis Xavier University}

Employment Contracts: New Zealand Experiences, edited by Raymond HaRbridge, Wellington, Victoria University Press, 1993, 253 p. ISBN 0-86473-241-4.

For the past 10 years, New Zealand has been in the grip of strident neoconservatism which has outlasted and surpassed Thatcherism. First under Labour and then a National government, New Zealand has endeavoured to marketize itself by deregulating, abolishing subsidies, selling state-owned enterprises and unravelling the social safety net. Shortly after the election of the National government in 1990, The Economist noted that the only significant remaining area for deregulation in New Zealand was the labour market. Labour had supported unionism and collective bargaining.

This book addresses the National Party government's drive to restructure industrial relations by passing the Employment Contracts Act, 1991. This experiment has made New Zealand a public policy laboratory for those who are interested in observing the implementation of a vision which is as precipitous a departure from the past as the one some one hundred years earlier in which it pioneered conciliation, compulsory arbitration and social partnerships. Harbridge and Hince observe that the Act decollectivizes or individualizes bargaining, decentralizes it to the enterprise level, and de-unionizes industrial relations. The Act does not use the word "union". Unions lost their exclusive rights to represent employees and the institutional underpinnings of the old regime were abolished, e.g. the Arbitration Commission and Trade Union Education Authority.

Walsh and Ryan discuss the political and policy making processes by which a powerful business lobby and its ideological cohorts in Treasury pushed toward and came up only slightly short of ending state involvement in the functioning of the labour market. Employment contracts are now treated in ways that are nearly indistinguishable from other common law contracts. Vestiges of the old order remain in special labour legislation dealing with contract mediation and arbitration which authors predict will be expunged if National is returned to power.

Assessing the Act's short term impact, Harbridge concludes that predictions that primary sector workers' conditions would improve, while those of secondary workers would deteriorate, appear to have been accurate. Some $45 \%$ of the previously unionized workforce (approximately 336,000 workers) in several sectors have been 
decollectivized, presumably placed on individual contracts of employment. Boxall writes sympathetically about the Act, arguing that it was necessary to break the old rigidities and bring the flexibility employers world-wide are pursuing. He credits the Act for New Zealand's improved competitiveness. He contends that while some firms have used reform to erode wages and working conditions, mainstream employers have not, for fear of destroying morale. Some organizations have used their new flexibility to introduce more cooperative schemes.

From Kiely and Caisley's review of case law which has emerged under the Act, one is struck by some employers' eagerness to use the Act to justify unilateral abrogation of employment contracts in ways which would be unthinkable if the contracts were with suppliers. Employers have asserted that the primacy of the right to manage should override the sanctity of employment contracts. The courts have held them to the legal standards for commercial contracts. McAndrew sketches the nascent structural outlines of contract coverage. His survey revealed that the majority of firms neither consult employees prior to drafting contracts nor make significant changes in them after "individual bargaining" has occurred.

The book is packed with interesting details and observations. It should interest anyone wanting to know what could happen if state support for collective bargaining and unionism were withdrawn. New Zealand's experiment allows one to glimpse the denouement of a neoconservative agenda. Although it is premature to draw conclusions about the final shape of this assault upon collective bargaining, its outlines are becoming evident. The book is a balanced collage, reflecting a number of perspectives, i.e. historical, union, management, legal and women's. It would benefit from an introduction to summarize the Act's provisions and the book's approach to the subject. As well, it needs a conclusion.

Kurt WeTzeL

University of Saskatchewan

From Socialism to Market Economy: The Transition Period, edited by William S. KERN, Kalamazoo, Michigan, W.E. Upjohn Institute for Employment Research, 1992, s. 5 + 134 p., ISBN 0-88099-129-1

This is a collection of academic papers presented during the 1990-91 school year at Western Michigan University. Paul Marer deals with the roadblocks to changing economic systems in Eastern Europe. Abram Bergson analyzes the Soviet economic reforms under Gorbachev. Joseph S. Berliner reviews the chances of reconstructing the Soviet planned economy. Paul R. Gregory explores the relationship between the Soviet bureaucracy and economic reforms. Herbert $S$. Levine examines some basic inconsistencies in the promotion of reform. Joseph Brada discusses the limited window of opportunity available to politicians who promote economic transformation in Eastern Europe.

The problems highlighted by the authors still remain valid. Private ownership is being implemented with great difficulty. Strong competition and free trade are far from being the driving forces of progress. A strong and convertible currency has been 